
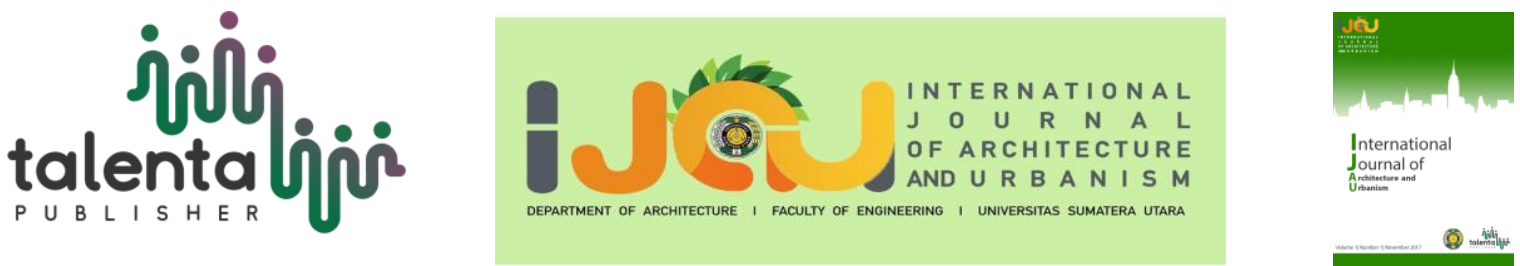

\title{
Analysis of Medan Sunggal Sub District Urban Spatial
}

\author{
Dewi Arini ${ }^{*}$ \\ ${ }^{I}$ Department of Public Works and Spatial Planning Serdang Bedagai Regency, Sei Rampah, Serdang \\ Bedagai, Indonesia
}

\begin{abstract}
This study is intended to determine the state of the spatial urban city in an area. This analysis aims to determine the morphological face of the city to determine the movement and development of the city in the future. The study area is located in Medan Sunggal Sub District. Medan Sunggal sub-district is one of the sub-districts in the city of Medan which borders Deli Serdang. According to the RTRW for Medan City, this area has a land-use as a residential area, but there is also economic growth in the form of commercial areas along the roads in all villages in Medan Sunggal sub-district. The discussion on urban spatial analysis in Medan Sunggal sub-district uses figure-ground analysis and Von Thunen's zone theory.
\end{abstract}

Keyword: land use, urban spatial, sub-district

Received date month year. | Revised 4 October 2020| Accepted 16 November 2020

\section{Introduction}

\section{Introduction}

The city as a whole includes two inseparable aspects, namely the physical aspect and the human aspect. The physical aspect as a form of space with its elements, then the human aspect as the subject of development and users of urban space [1]. The development of society in urban life has been shown as an activity that leads to a better life than before. A good form of urban space is an urban space that can provide life and comfort for its users. An increase in population can result in an increase in space requirements, while an increase in space requirements triggers the growth and development of urban areas [2].

Medan Sunggal sub-district is one of the sub-districts in the city of Medan which borders the Deli Serdang district. Medan Sunggal Subdistrict consists of 6 (six) villages, namely, Tanjung Rejo Village, Sunggal Urban Village, Lalang Village, Sei Sikambing C Village, Simpang

*Corresponding author at: Dinas Pekerjaan Umum dan Penataan Ruang Kabupaten Serdang Bedagai, Jl. Negara No. 300 Kec. Sei Rampah 20995 Serdang Bedagai Regency

E-mail address: dewiarini.bagoes@gmail.com

Copyright (C) 2020 Published by Talenta Publisher, 
Tanjung Village, and Babura Sunggal Village (Figure 1). This district has an area of $13.90 \mathrm{~km} 2$ [3].

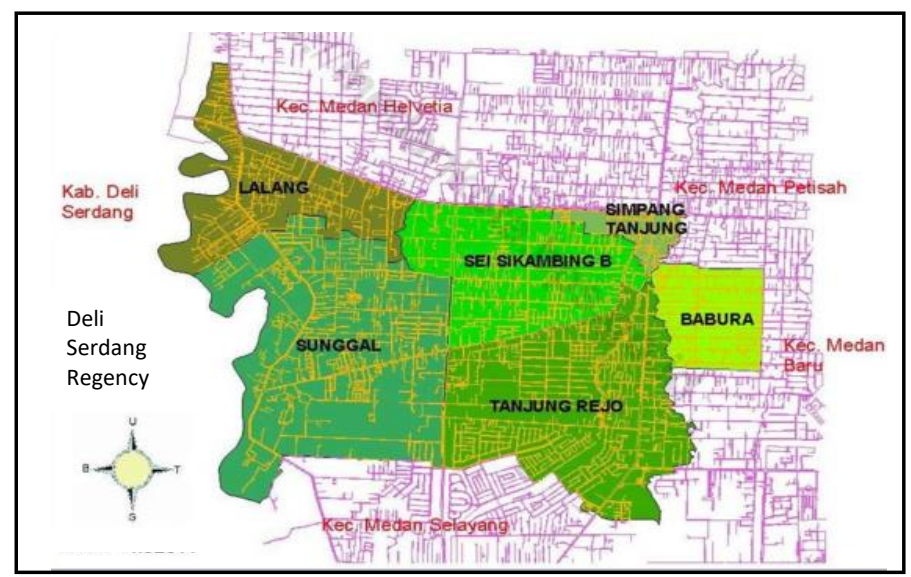

Figure 1 Map of Medan Sunggal Sub District

According to the RTRW, Medan Sunggal Subdistrict has the designation of most of the settlements and housing, but along with the development of the city, the construction of a ring road that crosses Medan Sunggal sub-district. This area is increasingly filled with commercial activities along the roads scattered throughout the sub-districts of the Medan Sunggal subdistrict. This situation makes this area quite strategic because of good road access. New settlements and housing have also grown to replace agricultural functions in the last ten years. According to the Detailed Spatial Plan and the 2015-2035 Zoning Regulations for Medan City, in Medan Sunggal Sub-district, it has been seen that the designation is dominated by commercial areas and residential areas (Figure 2).

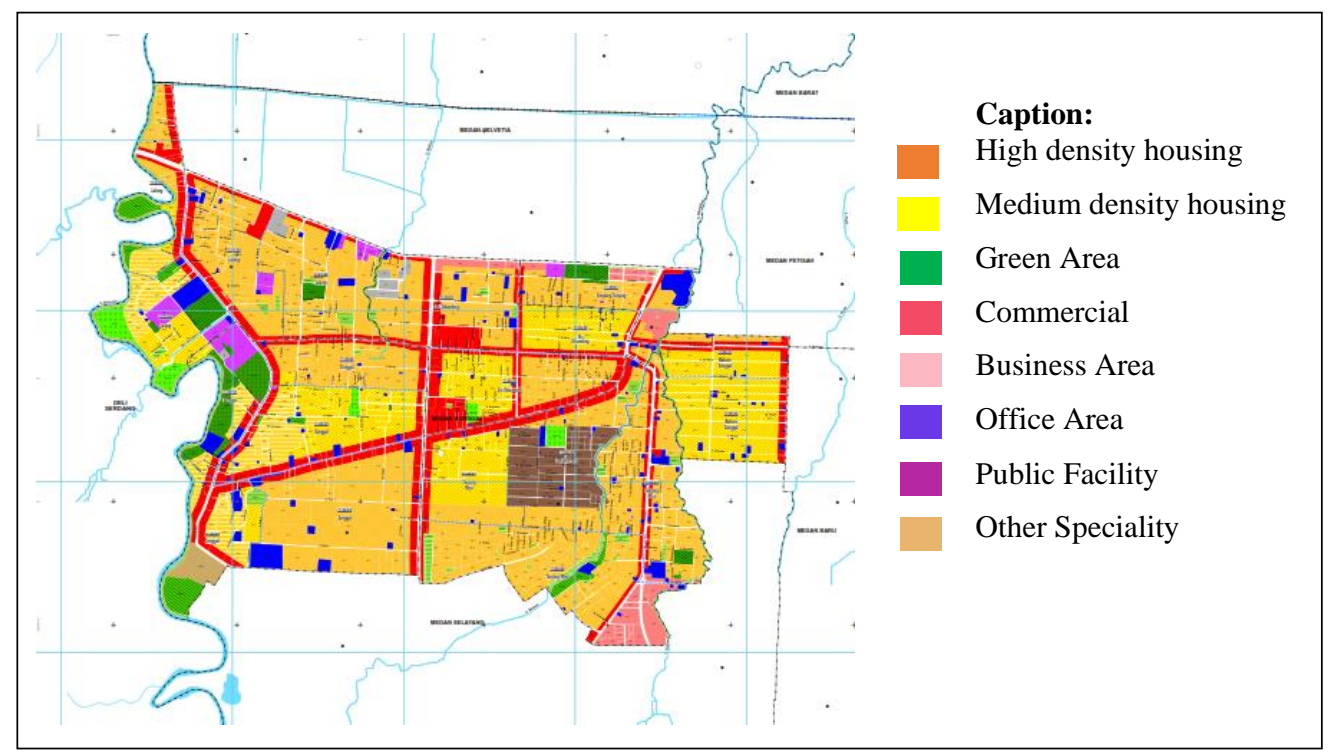

Figure 2 Rencana Detail Tata Ruang Kecamatan dan Peraturan Zonasi Medan Sunggal

An urban spatial analysis is intended to analyze spatial patterns in an area. The scope of understanding the concept of Spatial Analysis, in essence, is spatial on earth. The spatial 
analysis leads to a wide variety of operations and concepts including simple calculations, classification, structuring, geometric overlays and cartographic modelling. This urban spatial analysis serves to show the actual spatial pattern in an area in the current research study area in Medan Sunggal District [4].

\section{Research Method}

This research is qualitative. Qualitative research is a type of research that produces findings that cannot be generated using statistical results or by means of measurement [5]. Processing the data obtained in the field is to determine the morphology of the polar shape of the Medan Sunggal sub-district by performing several analyzes. The form of city morphology is the study of changes in urban patterns and layout by looking at the arrangement that is always changing and the addition of city-forming layers that occur during the long process of city development.

Data collection was carried out by using secondary data collection methods. Secondary data collection can be obtained by examining source related documents such as maps or satellite imagery. The document is the Detailed Spatial Plan for the City of Medan Sunggal, which was ratified in 2015 as the basic material for knowing the land use function in Medan Sunggal District.

\section{Result and Discussion}

The analysis carried out is descriptive of the theory based on the data that has been obtained. This analysis technique consists of morphological analysis and urban land use analysis. Stages of analysis are carried out based on predetermined methods used to explain the dynamics of regional growth and increase in land requirements, trends in the spatial patterns of Housing and Settlement Areas as well as the driving factors for housing and settlement growth.

The use of land in the study area can be viewed from a functional perspective, namely as a function of buildings and services for land consisting of dense residential areas, medium settlements, office areas, trade/service areas, commercial areas, public service areas, and green open space areas. Conceptually, the area in the study area can be seen from the existing theory more towards the von Thunen zone land use theory model, where there is a core area as a centre of activity followed by residential/housing and trade areas as well as agricultural areas at the back [6], as well as location theory. Location theory is a science that investigates the spatial order of economic activity or science that investigates the geographic allocation of potential sources, as well as their relationship with or their influence on the existence of various kinds of economic and social activities [7].

The spatial pattern in Medan Sunggal Subdistrict is a series of overall urban developments. According to the RDTR of Medan Sunggal Sub-district, land use in Medan Sunggal sub-district 
is dominated by settlements with commercial or commercial areas (Figure 2) [8]. For that, it can be analyzed by analysis of city morphology. Morphological analysis is used to analyze the spatial form expression of the city, which does include not only visual product display (city as a product) but also involves non-physical elements that take part in the process of change (city as a process) [9]. There are three basic theories used to determine the shape and pattern of city space, namely figure/ground, linkage and place theory [10]. However, the elements of this research are more emphasized on figure/ground analysis with solid elements and void elements as their constituents, where this analysis can be used in addition to identifying a texture and urban spatial patterns as well as being used to determine mass regularity in urban space. In this analysis, mass can be analogized as a built-up area (solid), while space can be analogized as open space or empty land (void). These two elements also function to determine the direction of settlement distribution and regional pattern.

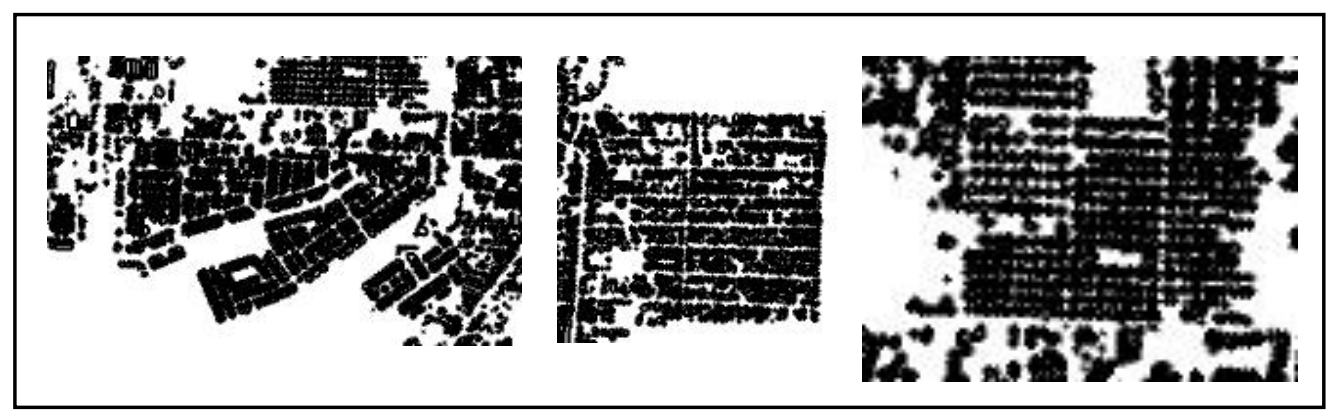

Figure 3 Figure-Ground TASBI, Housing at Kel Babura Sunggal, and Housing Kodam $\mathrm{I} / \mathrm{BB}$

It can be seen in Figure 3 that there is a mixed pattern in the Medan Sunggal sub-district. An organized solid element can be seen in the housing locations in several housing complexes around the Tanjung Rejo sub-district (Taman Setia Budi Indah), Kodam I / BB Housing, Somerset Housing and Bumi Seroja in Sunggal Kelurahan. Interestingly, there is a grid pattern in settlement of Babura Sunggal village (Figure 4). A study [12] found the grid plan to be the least safe by a significant margin with respect to all other street patterns.

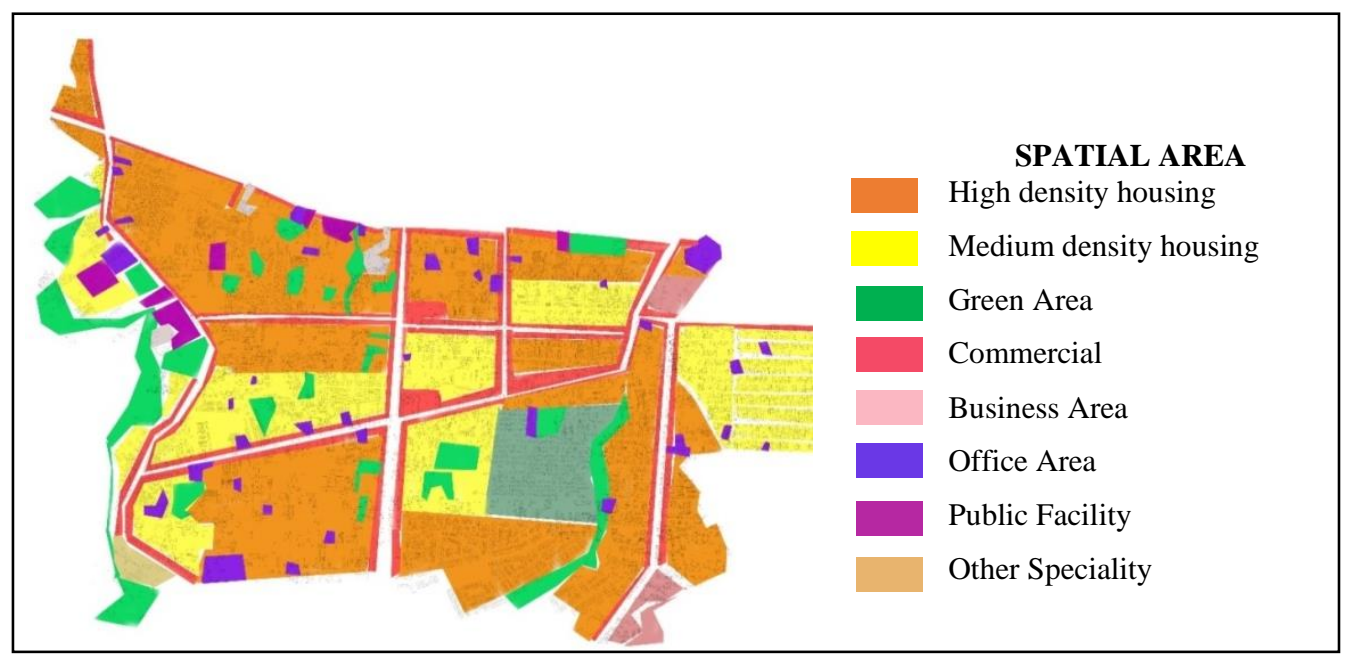

Figure 4 Land Use Existing at Medan Sunggal Sub District 
Interestingly, the urban area, when seen from the distribution of commercial businesses is along the primary road in Medan Sunggal sub-district. This area is divided into all villages in the Medan Sunggal sub-district. This area can be seen on the ring road, Sunggal street, Amal road, Gatot Subroto street, Setia Budi street, and TB Simatupang street. The existing land use pattern is shown in the figure above (Figure 4).

Thus, it can be seen that the shape of the Medan Sunggal sub-district as an expression of the urban space is included in a spreading pattern because the urban area has been spread out as evidenced by the commercial/service trade area along the road. The most rapid development in the Medan Sunggal sub-district is currently along the ring road because of the wide road facilities. The infrastructure system can define as physical facilities or basic structures, equipment, installations built and what is needed for the social support system and system the economy society [13]. The growth in building density and activity is influenced by the role of these roads. The physical development of the building was slow on Jalan TB. Simatupang and Jl. Bunga Raya, because the designation of this area (sub-districts of Sunggal and Lalang) is for green open space and public infrastructure. Public infrastructure in this area is in the form of government offices (State Personnel Agency, Ministry of Religion Education and Training, Medan City Public Works Office) and public infrastructure at Pinang Baris Terminal. Areas with less than optimal road access are usually dominated by office activities and less dense density [11]. Meanwhile, the distribution of residential areas in the study area tends to be more of a regular distribution pattern because the residential areas are located on secondary roads.

The urban morphology approach is one related approach directly with aspects of urban and rural land use highlight the spatial existence in the manifestations of the characteristics [14]. The von Thunen approach likening the centre of the economy is a city surrounded by land whose quality is homogeneous. The resulting land use can be presented as concentric rings that surround the city [15]. In Sunggal Medan Sub-district it can be seen that the location of the trade centre surrounds the housing settlement.

\section{Conclusion}

Based on the results of the analysis that has been done, it can be concluded from research on spatial patterns in Medan Sunggal Subdistrict, which are as follows: (A) Based on the comparison of satellite imagery in 2020 and 2015, it can be observed that commercial business growth spreads along the primary roads in Medan Sunggal District. (B) The pattern of land use in Medan Sunggal sub-district is observed more in spreading land use, where there is a central area for goods and services activities or trade around residential areas and the designation of green open spaces is in the western part or borders with Deli Serdang Regency. (C) Spatial patterns in Medan Sunggal Subdistrict analyzed through morphology lead to an irregular spread (Sprawl) when observed from the overall physical form. (D) Medan Sunggal currently the 
fastest growing area is along the ring road. Supported by wide and good road conditions, the growth in building density and activity is influenced by the role of the road lane. The growth of the commercial area also occurred along other collector roads, such as Sunggal Street, Amal Street, Setia Budi Street, and Kasuari Street. (E) Green Lane or Green Open Space is less visible in residential areas.

\section{REFERENCES}

[1] Sugiono Soetomo. Dari Urbanisasi ke Morfologi Kota. Semarang. Badan Penerbit Universitas Diponegoro.2002

[2] N. Daljoeni. Geografi Kota dan Desa. Bandung, Alumni. 1996.

[3] Badan Pusat Statistik Kota Medan, Kecamatan Medan Sunggal dalam Angka Tahun 2020 (cat. No. 1102001.1275110). Medan : BPS, 2020. [Online]. Available from BPS, https://medankota.bps.go.id/publication/2020/09/28/b4ec9b93e67b0104fc076908/kecama tan-medan-sunggal-dalam-angka-2020.html. [Accessed : Oct. 31, 2020].

[4] De Mers. Fundamentals of Geographical Information System, Canada, John Wiley \& Sons. 1997

[5] H. Noeng Muhadjir. Metodologi Penelitian Kualitatif. Yogyakarta. Rake Sarasin. 1996.

[6] "Von Thunen, A Model of Agriculture Land Use" [Online]. Available : https://www.gcsnc.com/site/handlers/filedownload.ashx?moduleinstanceid=46351\&datai $\mathrm{d}=55533 \&$ FileName$=$ Von-Thunen-model-reading.pdf [Accessed : Oct 30, 2020].

[7] R. Tarigan. Perencanaan Pembangunan Wilayah, Edisi Revisi, Jakarta. Bumi Aksara. 2006

[8] Pemerintah Kota Medan, Rencana Detail Tata Ruang (RDTR) dan Peraturan Zonasi Kota Medan 2015 - 2035. Medan, 2015.

[9] H. F. Rachman. "Kajian Pola Spasial Pertumbuhan Kawasan Perumahan dan Permukiman di Kecamatan Limboto Kabupaten Gorontalo," thesis, Universitas Diponegoro, Semarang, 2010.

[10] Markus Zahnd. Model Baru Perancangan Kota yang Kontekstual : Kajian tentang kawasan trasidional di Kota Semarang dan Yogyakarta - Suatu potensi perancangan kota yang efektif. Pg. 67. Yogyakarta. Kanisius 2007

[11] Pemerintah Kota Medan, Rencana Tata Ruang Wilayah Kota Medan 2010-2030. Medan. 2010.

[12] J. Sun and G. Lovegrove. Evaluating the Level of Safety of the Fused Grid Road Pattern. Ottawa: Canada Mortgage and Housing Corporation, 2009.

[13] Neil S. Grigg. Infrastructure Engineering and Management. Printed in the United States of America. John \& Sons, Inc. 1987.

[14] S. Hadi Yunus. Dinamika Wilayah Peri - Urban, Determinasi Masa Depan Kota.. Yogyakarta : Pustaka Pelajar. 2008.

[15] Edy Darmawan. Ruang Publik dalam Arsitektur Kota. Semarang. Badan Penerbit Universitas Diponegoro. 2009. 